Globalization, Comparative Political Economy and the Economic Policies of the Blair Government

Wyn Grant

CSGR Working Paper No. 08/ 98

June 1998
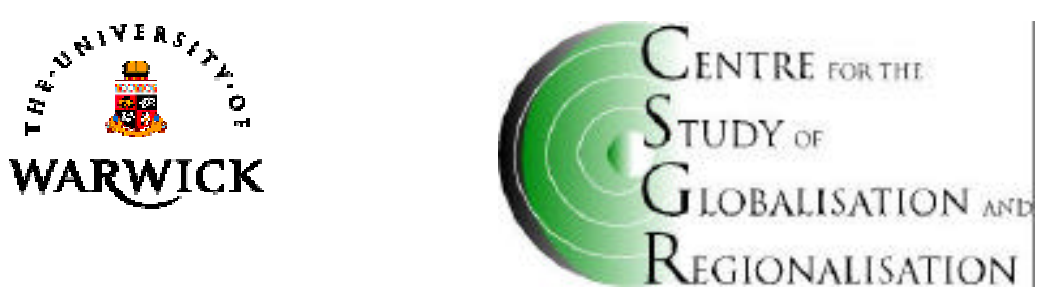

Centre for the Study of G lobalisation and Regionalisation (CSG R), University of Warwick, Coventry CV4 7AL, United-Kingdom. URL: http://www.warwick.ac.uk/fac/soc/CSGR 
Globalization, Comparative Political Economy and the Economic Policies of the Blair Govemment

Wyn Grant

University of Warwick, CSGR Working Paper No. 08/ 98, June 1998

\section{Abstract}

This paper critically examines attempts to revitalize the comparative political economy model in contrast to analyses based on a globalization perspective. The organized market economy approach of Peter Hall is seen as a more inviting version of the CPE model. The political dilemmas facing national governments in an era of globalization are examined through a discussion of the economic policies of the Blair Government in Britain.

Key Words: Globalization, European Union, Blair Government

Address for correspondence:

Wyn Grant

Department of Politics and International Studies

University of Warwick

Coventry CV4 7AL UK

E-mail: W.P.Grant@Warwick.ac.uk 


\section{Non-technical summary}

Globalization can be hard to define, but that doesn't mean that it doesn't exist. The paper assumes that there is some kind of step change in the world order, although discussing its nature and extent is not the objective of this paper.

What the paper does do is examine critically the stance of the comparative political economy school, as particularly represented by a recent book edited by Colin Crouch and Wolfgang Streeck. This book represents an attempt to revitalise an approach which emphasises the ways in which national differences can help or hinder the international competitiveness of a particular country. Crouch and Streeck are worried that American forms of capitalism will displace German forms of capitalism through the effects of globalization.

Their analysis is in many ways a well argued one, but the whole emphasis is on institutions. One would not think that individual entrepreneurs like Richard Branson had ever achieved anything. Crouch and Streeck seem to take the view that firms compete through the benevolence of their governments.

They also underestimate the importance of new governing entities below and above the level of the nation state. Policies to promote skill formation or nurture high value added activities can often be done most effectively at a subnational level. The European Union is mentioned very little in their analysis and when it is rather negatively - seemingly because it can't replicate the German way of doing things on a European scale. No one denies that there is a paradox at the heart of the EU because it both facilitates globalization and tries to offer social protection from its effects.

Peter Hall's analysis of organized market economies is seen as a more fruitful approach, if only because he recognizes to a greater extent than Crouch and Streeck the weaknesses of organized market economies. They may, he admits, slow down necessary processes of adaptation and change. Even Germany cannot go in the same way, but it may be able to preserve the essential features of its model while making necessary changes.

It is evident that globalization presents national governments with a challenge in managing their economic policies: they have to promise economic success to voters, but can they still deliver? It is argued that the Blair Government in Britain has shown an awareness of the limits of what they can do, but also of the limits of autonomous action. They have been politically astute, although they have to walk a tightrope between fiscal restraint and delivering on promises of better schools and hospitals.

There is a democratic deficit at the global level, but attention should be focussed on this and on new regional and subnational forms of government rather than seeking to shore up the resistance of existing national models to change. 


\title{
GLOBALIZATION, COMPARATIVE POLITICAL ECONOMY AND THE ECONOMIC POLICIES OF THE BLAIR GOVERNMENT
}

\author{
Wyn Grant
}

\begin{abstract}
Globalization and comparative political economy offer different perspectives on the analysis of developments in world political economy. One does not have to accept the extreme pronouncements of writers like Ohmae (1990) to recognise that globalization is a phenomenon which has the potential to reduce the significance and autonomy of the nation state. Globalization is understood in this paper as a continuing process which reduces the significance of national boundaries as an impediment to the free movement of capital, labour, goods and services. Barriers have particularly diminished in the international capital market and remain generally high in relation to labour migration, but the general picture is clear. Indeed, the fact that the definition of globalization is sometimes imprecise is a rather poor argument for dismissing the significance of the phenomenon.
\end{abstract}

A recurrent theme in both the literature and more popular accounts is that globalization represents nothing new, that at most it is an acceleration of a movement towards greater economic integration and interdependence that has been taking place over a long period of time. Thus, for example, Vandenbroucke argues, 'A cool look at globalisation reveals no significant new and hard economic facts behind the replacement of the traditional expression "the international econoomy" by "the global economy."' (Vandenbroucke, 1998, p.30). The purpose of this paper is not to argue whether or not globalization represents a paradigm shift in the organization of the world economy rather than, say, an acceleration along an existing path. Nevertheless, the assumption is made that something significant is happening and that, for example, the replacement of GATT by the World Trade Organization does represent a step change in the organization of the international trading regime. However, the focus here is on responses to the perceived phenomenon of globalization, rather than debating whether or not a meaningful change has occurred. Certainly, this paper does not subscribe to a new form of economic determinism which argues that there is only one, liberal path which the world economy can follow. 
The comparative political economy approach

The comparative political economy approach emphasises the diversity of environments which nation states provide for their economies. The term 'approach' is used deliberately as different authors provide a range of models within the general orientation. The underlying argument, however, is that different institutional environments and different national policy paths have a discernible impact on the competitiveness of firms based in a particular nation state. When this literature enjoyed its finest hour in the 1980s, the implicit case being made was that countries with relatively low levels of institutional development would benefit from becoming more like those who had dense institutional networks. Thus, the American 'declinist' literature suggested that the United States should attempt to learn from Japan. At its crudest and most banal, this degenerated into a call for an American 'MITI' (although some would say it already existed in the Department of Defense). Institutions do not easily transfer from one setting to another and it was more consistent with a true 'requisite variety' position to suggest that Americans should try to adhere to their own values and strengths. (Fallows, 1989) Some of the other distinctive institutional settings which were discovered by expeditions of social scientists (such as the 'Third Italy') turned out on closer scrutiny to be more complex, flawed and limited than the first dispatches received suggested (Nuti and Cainelli, 1996) and not always well placed to cope with internationalization (Tamisari, 1997).

In the 1990s, the American economy has been restored to new heights of prosperity and even Britain has not done so badly while Germany has struggled with high unemployment and Japan with financial crisis and the new and unwelcome experience of appreciable levels of unemployment. Faced with the apparent dominance of what they saw as an uncritical neo-liberalism comparative political economists convened at two conferences in France in 1994 under the aegis of the Andrew Shonfield Association. Following on from these conference, the capitalist diversity model is re-visited, re-stated and re-assessed in a recent volume with contributions from some of the leading figures in this field (Crouch and Streeck, 1997). This paper also offers a discussion of an analysis by Hall which, although in the same comparative political economy family, takes a somewhat different - and, it is argued, more convincing - direction. 
Interestingly, the Crouch and Streeck volume contains a dissenting chapter by Susan strange (1997) who herself played a not insignificant role in the emergence of Shonfield's classic work. (Shonfield 1964). In the past, the present writer has had some walk on parts in the comparative political economy literature (Grant, 1989). However, with the millennium only two years away, the time has come for a complete change of kit. A new orientation was already presaged in an earlier paper on the stateless firm. (Grant, 1992). That is not to say that this paper writes off the nation-state. There have been too many premature obituaries. It still has a lot of life left in yet, particularly in the area of what may be broadly termed social welfare.

\section{The objectives of this paper}

This paper seeks to fulfill a number of tasks. First, it presents a short summary of the arguments put forward by streeck and his colleagues. Second, it attempts to identify a number of deficiencies in their work. In particular, it is suggested that rather than their argument that 'I have seen the future and it is bleak', a more appropriate line might be 'I have seen the future and it is complex'. It is also suggested that streeck in particular underestimates the significance of the European Union because it has disappointed him by not replicating the German economic and social settlement on a European scale. Third, it looks at the work undertaken by Hall which has proceeded on the basis of a collaboration with Soskice. (Hall, 1997; Hall and Soskice, forthcoming). The final part of the paper looks at the approach to economic policy of the Blair Government in Britain and shows that they have made a shrewd calculation of what is and is not possible in an era of globalization. The paper concludes by suggesting that both Crouch and Streeck and Strange have identified the crucial question: what transnational forms of governance can be found to substitute for the nation-state?

\section{The Crouch-Streeck line}

Wolfgang Streeck has had a long and distinguished career as an analyst of modern capitalism with a particular emphasis on the virtues of the German model. His empirical work has focussed on the automobile industry, trade unions and business interests. His co-editor and co-author, Colin Crouch, is an acknowledged expert on industrial relations and someone who has long emphasized the 
deficiencies of the Anglo-American model of capitalism. Consistency, coherence and intellectual rigour are great virtues, but the price paid can be a lack of intellectual flexibility.

Crouch and Streeck's opening chapter is a tour de force. One might expect the cast members of Third Rock from the Sun to be seen with it as part of the essential reading recommended for any aliens on a study visit to earth. The essence of the crouch and Streeck argument is simple: the capacity of the nation state to sustain institutional diversity is being eroded by globalization and this is not good news. As they put it the processes of globalization are likely 'to favour those national capitalisms that have in the past done with comparatively little state intervention, over those institutional economies that required a high level of state-mediated political organization, thereby affecting the relative competitiveness of alternative performance patterns.' Capitalist economies will tend to converge on 'an institutional monoculture of deregulated markets and hierarchies, thereby reducing the overall diversity of available governance arrangements and potentially causing a net loss in overall economic performance.' (Crouch and Streeck, 1997, p.13).

Since this last point is one of their strongest ones and central to their argument, their case requires a little more attention. Crouch and Streeck argue (1997, p.15):

To the extent that national or other specificities serve as niches allowing firms and economies to develop competitive new products and processes, their disapperance must diminish the aggregate entrepreneurial creativity and vitality of capitalism as a system. It is further highly unlikely that any one approach to running a capitalist economy will monpolize all the virtues - which would seem to offer good ... reasons for seeking to preserve the innovative potential inherent in a healthy level of 'socio-diversity' within global capitalism.

In his chapter on Germany, Streeck expresses his fears with even greater clarity. Globalization is seen as eroding the conditions for market modifying political intervention, leaving only depoliticized and market driven forms of economic order. Streeck makes clear his distaste for the 'anarchic world of international politics', which certainly does not offer the kind of regulated Ordnungspolitik favoured in Germany. Globalization favours 'national systems like those of the USA and Britain. This will lead 
to the 'perverse outcome of the less well-performing Anglo-American model of capitalism outcompetng the better performing "Rhine model"'. (Streeck, 1997, p.53).

\section{The limits of the analysis}

This claim that the Rhine model has a better performance record could be the subject of a book by itself, but it cannot go entirely unchallenged. Part of the problem is that any assessment involves value judgements: does one prefer an economy like the United States which creates many jobs, but often at low wages and with considerable overall social inequality; or does one prefer the German approach of high wage jobs, relatively low inequality, but high unemployment (albeit partly the consequence of unification which plays a central role in Streeck's account; Hall also mentions the need to meet EMU convergence criteria).

Britain comes in for particular criticism, and in many ways it is an easy target. Graham in his chapter provides a trenchant account of what is seen as the failure of Conservative capitalism. Of course, Britain has a long record of relatively poor economic performance under a variety of policy regimes. A spokesman in the House of Commons is once said to have remarked, 'Every available policy option in this country has been tried at least once, and every option has failed', bringing the retort from the benches opposite, 'including you'.

One hesitates to challenge an analyst and practitioner with such a distinguished record as Graham. However, it is interesting that Crafts is cited in the introduction as an economist sympathetic to institutional perspectives. One hesitates to summarise the rich oeuvre that Crafts has produced on the Thatcher Government. However, in terms of stylised facts his analysis runs as follows: policy mistakes were made, particularly in terms of a failure to act sufficiently quickly on education and training. However, compared to past performance, manufacturing productivity improved, as did overall macroecnomic performance. In part this can be attributed to the removal of the veto power of the unions and the constraints placed on management. (Bean and Crafts, 1996; Crafts, 1997). In other words, British economic performance may not be good after the marketization of the economy, but it is no worse than it was, and in some respects is better. 
One of the difficulties with the analysis presented in the volume is that it is completely focussed on institutional factors. The role of the individual entrepreneur is completely ignored. There is no room for the Richard Bransons or the Alan Sugars of this world. As Strange points out, 'The success of the economy does indeed depend heavily on quick responses, on adaptability and competitive costs. But these are attributes of corporate management, not of government officials or politicians.' (Strange, 1997, p.184). As Porter observes, 'Firms, not nations, compete in international markets.' (Porter, 1990, p.33). The perspective in this book seems to be that firms and entrepreneurs are allowed to compete through the benevolence of their governments and other social institutions. Nothing can be created outside the mantle of the state and other social institutions. If Richard Branson had wanted to start a business in Germany, he would have probably have to have obtained a Handwerk qualification and would then have found that the opening hours of his shops were restricted.

\section{Below and above the nation state}

In the world of Crouch and Streeck, 'the politics that was supposed to generate capitalist diversity was national.' (Crouch and Streeck, 1997, p.2). As a consequence, Strange notes that 'they are still looking within national societies for possible alternatives to government intervention to modify the social consequences of global economic integration.' (Strange, 1997, p.182). But perhaps Crouch and Streeck are looking in the wrong place for the holy grail of capitalist diversity: perhaps they should be looking above and below the nation state.

We live in a period which seeks to give political expression to subnational identities. Whether the transaction costs of federal or quasi-federal systems are less than the political benefits they bring is a question beyond the scope of this paper. What is not surprising is that one reaction to globalization is to cling even closer to very specific local identities. For example, the rebirth of Scottish identity has come at a time when the Scottish economy is more under international control than ever before.

Scotland has, however, shown an ability to nurture high value added products in specific market niches, e.g., specialist woollen goods or particular branches of food processing. The 'Scottishness' of these goods is often used to market them: note, for example, the 
advertising campaigns of the food processing firm, Baxters, which uses family members both to stress family ownership and control and the distinctive Scottish character of the products. A Scottish legislature and executive is well placed to nurture such activities. For example, it can protect and develop the distinctive and in some ways superior Scottish education system thus enhancing human capital formation.

The subnational dimension is largely neglected in the Crouch and Streeck volume, somewhat surprisingly given that in the introduction they state that 'economic governance regimes will vary between subnational regions'. (Crouch and Streeck, 1997, p.16). The role of banks owned by Land governments in providing funds for small businesses is acknowledged (Pontusson, 1997, p.63), but federalism is seen as a constraint that differentiates Germany from Sweden (Pontusson, 1997, p.61). In Streeck's account, federalism is presented principally as 'an extensive redistributive system of revenue sharing.' (Streeck, 1997, p.38). Distinctive Land level experiments in high technology policy are ignored.

It is not being suggested that Europe is going to become a patchwork quilt of capitalist diversities nurtured by subnational governments. However, the subnational dimension does repay some attention. In some ways, the most intriguing possibility is that emergent regional identities which cut across national boundaries will become more important and provided the basis for some kind of publicly sanctioned collective action. (Grant, 1997, p.218).

\section{The European Union}

The single biggest criticism to be made of the crouch-Streeck analysis is that it downplays the potential significance of the European Union. The European Union is discussed surprisingly little in the book and when it is mentioned, the perspective taken is a rather negative one. Put at its most simplest, the argument of the book's editors is that the quasi-state of the European Union lacks the capacity both to create or protect capitalist diversity or to offer European citizens social protection. They are not claiming that governance institutions are absent in Europe, but that they 'will probably lack the specific "market distorting" capacities of the traditional European nation-state.' (Crouch and Streeck, 1997, p.12). They are also concerned that 'the failure to establish a European state capacity would seem to be particularly devastating to 
the social base of the European economies.' (Crouch and Streeck, 1997, p.14).

Streeck makes it clear that in his view, 'the European quasi-state has no capacity to provide for equalization of living conditions in its territorial subunits.' (Streeck, 1997, p.52). His view is that German 'efforts to endow the Internal Market with a "social dimension", in alliance with the French and against the British, came to naught.' (Streeck, 1997, p.51). From a British perspective, this observation seems rather strange. The much argued about Social Chapter has a largely symbolic importance, but the European Commission, largely supported by the Court of Justice, has sought to extend the rights and protections of European workers. The resultant arrangements undoubtedly full well short of what Germany has been able to provide, as one might expect given both the dispartity between German GDP per capita and that of most other member states, and the necessary compromises forged in what is still an intergovernmental bargaining process more often that not. Nevertheless, the European social space is more than a lowest common denominator and contains elements of 'levelling up' as well as 'levelling down', e.g., legislation on working hours.

There is, of course, a paradox at the heart of the European Union. On the one hand, it clearly facilitates globalization by removing barriers to capital and trade at a regional level. American multinational companies have been strongly represented politically at the EU level. On the other hand, it seeks to offer protection against globalization by creating a distinctive European social space. The arena in which the EU has done this most successfully is that of agriculture, albeit at a somewhat high price in terms of budgetary expenditure, the cost to consumers and, perhaps most serious of all, the ability of European food products to compete on international markets. The experience of the CAP does at least demonstrate that the $\mathrm{EU}$ is able to offer social protection. Indeed, as the competitive pressures from trade liberalization intensify, the EU is asserting even more strongly the distinctiveness of a European agricultural model.

The European project has always been concerned with countering American hegemony, and as Strange emphasises:

There is a growing asymmetry of regulatory power among the governments of capitalist enterprises. The government of the USA 
exercises a global reach over enterprises and markets in other countries. It is a global reach unmatched by any other government. (Strange, 1997, p,.189).

In a post-cold war era where G1 solutions may seem attractive to the United States, the European Union has the ability (and the duty) to assert that there are other voices to be heard in the organization of world regulatory space. This has to be done with some political skill if one is not to play into the hands of the 'America First' tendency that is so prominent in the US Congress. The EU did play its hand quite well in the Uruguay Round negotiations, although perhaps its greatest success was defending the CAP. The EU needs more strategic focus in the way it which handles its external relations and it needs a clearer definition of what the European position in the world economy is, beyond protecting marginal farmers or French language films.

Old style social regulation of the heavy handed German kind is not going to survive or, if it does, Europe will not be able to compete effectively in the world economy. That does not mean that Europe should neglect its social dimension or try and create an American economy in which valet service is always available for your car whether you want it or not. Young business leaders at the 1998 Davos forum claimed that it was the social system not the economy that had broken down in Europe, with the burden of unemployment carried by the weakest individuals such as the young. (Financial Times, 31 January 1998).

What we face is a more complex world than that envisaged by the comparative political economists and hence one that requires more political sophistication to manage it. 'The "global" economy is ... a complex and often contradictory story of global markets, national development strategies, regional dynamics, and competing corporate strategies.' (Borrus and Zysman, 1997, p.143). Capitalist diversity of a kind that gives real competitive advantage will be nurtured at three levels. The European Union has a strategic role in defining and defending the nature of the European economic and social space. Nation states will continue to have an important role in education and training and hence in human capital formation. If arrangements like the German Handwerk or the Italian artisanal associations are superior in these and other areas, then their institutional distinctiveness need not be threatened. Finally, there is an important role for the subnational level, particularly in marketing 
and maintaining quality standards for distinctive high value added products.

\section{The organized market economy model}

Peter Hall of Harvard University is one of the best known figures in the field of comparative political economy. The discussion presented here will rely on a paper presented at the eleventh International Conference of Europeanists in Baltimore in February 1998 (Hall, 1998), but also on a contribution to the WzB Jahrbuch (Hall, 1997). The Baltimore paper is a draft and Hall emphasizes that his answers are 'tentative'. Nevertheless, there are a number of inviting aspects to his approach which merit discussion.

Hall draws a distinction between liberal and organized market economies (following Soskice, the term used in the 1997 piece is 'coordinated market economies'). In comparing these models he recognizes that 'There are some significant differences among nations that might be described as coordinated or liberal market economies; and, within any one of them, some firms will find ways of pursuing corporate strategies that the overall institutional structure does not seem to encourage. ' (Hall, 1997, p.8). However, an overall stylized comparison is appropriate in terms of moving the debate forward and Hall is interested in the particular strengths and weaknesses of these different economic models and specifically in the question of whether they the organized market economies can secure lower levels of unemployment without abandoning their economic model altogether. In developing his argument, he acknowledges his debt to models offered by soskice.

In Hall's approach, the idea of a liberal market economy is reasonably equated with an Anglo-American model. He sees the idea of the organized market economy having evolved over time with its roots in the debate about neo-corporatism and coordinated wage bargaining. However, Hall shrewdly moves beyond this particular label which has often seemed to obscure as much as it has clarified. The liberal market economy seeks to deal with coordination problems through competitive market mechanisms and short-term contractual relations. Such economies are 'generally characterized by a system of corporate governance in which owners or providers of finance remain distant from the development of corporate strategy and use fluctuations in the share price of the firm as the principal basis for their investment decisions.' (Hall, 1997, p.7). The organized 
market economy 'is defined by the extensive degree to which it relies on institutions other than market mechanisms to resolve the coordination problems facing firms.' (Hall, 1998, p.3). For example, suppliers of finance may be involved in corporate governance, providing sources of finance 'that do not turn on share-price.' (Hall, 1997, p.8).

Hall recognizes to a greater extent than the Crouch and Streeck authors the weaknesses of an organized market economy approach. Redeployment of resources in such an economy may take place rather slowly because it involves renegotiation with multiple actors. As a consequence, such economies 'have generally been slow to shift resources across sectors and into new sectors... in this respect the structural framework of a liberal market economy seems more propitious.' (Hall, 1998, p.16). One might add that a global economy may have the effect of increasing the pace of change, facing organized market economies with new and difficult dilemmas.

Hall presents an extended discussion of globalization, arguing that it has had particularly strong effects on western Europe. What is a little surprising is his definition of globalization 'as a set of processes that have made it more feasible and desirable for companies to locate at least some of their operations abroad.' (Hall, 1998, p.16). This paper has preferred a broader definition of globalization and finds Hall's definition rather restrictive. Hall's subsequent discussion, although stimulating, has rather different concerns from those of this paper. He does call into question 'the presumption that the business community of each nation will automatically press the state for greater deregulation in order to cope with globalization.' (Hall, 1998, p.19). While 'pressures for deregulation may come from some quarters, there is likely to be substantial resistance to it from large segments of the business community.' (Hall, 1997, p.11). Thus, his discussion of Germany leads him to the conclusion that 'fears that Germany will be forced to adopt an Amglo-Saxon economic model are greatly exaggerated.' (Hall, 1997, p.21).

The subsequent analysis of Britain presented here suggests that it may be the politicians who are the key actors. This is not because they are following any particular set of demands from the business community, but either because their judgement is affected by what they believe to be the siren voices of globalization or, more likely, because globalization offers them an alibi for administering 
unpleasant medicine in the social sphere which they would wish to use anyway.

There are three points in Hall's analysis which are particularly persuasive. First, there is his acceptance that organized market economies do have some weaknesses and problems. Second, he accepts that some changes must follow in a changed global environment: 'These economies will certainly be called upon to make significant adjustments in their regulatory regimes in the context of the dramatic changes taking place in the international economy.' (Hall, 1998, p.25). Third, and most intriguingly, he suggests that it would be possible to bring about selective deregulation without setting organized market economies on the slippery slope to full deregulation. In the German case, although 'I have identified several respects in which the institutional structures of the German political economy will come under strain... there is reason to believe that these structures can accommodate some change without losing any of their distinctive strengths.' (Hall, 1997, p. 21).

Streeck would argue that this could be done without unravelling a normative consensus based on income equalization. Hall thinks that some change could be possible without damaging the intricate processes of non-market coordination on which organized market economies depend. He believes that 'these coordination processes may be more robust, in the face of international pressure and some deregulation, than we often suppose.' (Hall, 1998, p.25). His approach might be characterized as both more optimistic and more realistic than that of streeck in particular and he offers some interesting arguments which merit further discussion and investigation.

\section{The political dilemma of national governments}

According to the Crouch-Streeck model, national governments face some difficult dilemmas in attempting to manage their economic policies. In essence, they still have to promise, but their capacity to deliver has been significanty reduced. 'Hesitant to reveal to their voters the dirty secret that it is no longer they who determine their country's economic policies, national governments must somehow manage to extract from the democratic process policies that conform to the "general will" of global capitalism: the will of "the markets"'. (Crouch and Streeck, 1997, p.11). 
The general argument that will made here is that the Blair Government is handling the political challenge of globalization rather well. It must be emphasized that what is being discussed here is overall strategy rather than particular policy decisions (such as that to rule out membership of EMU for the lifetime of the current Parliament which seems to have driven by political factors rather than economic considerations).

Above all, the Blair Government has shown an awareness of the limits of what they can do, but also of the possibilities for autonomous action. They do perhaps have one advantage over some other national governments in that they do not face 'a potentially destabilizing "democracy illusion" among citizens, to the extent that these continue to expect national politics to offer them protection against market forces.' (Crouch and Streeck, 1997, p.10). The Blair Government has been handed an economy in which the overwhelming majority of inefficient firms and sectors are no longer in business and in which the public no longer expects, as it did in the 1970s, that government will bail out businesses in trouble. The public does have expectations in relation to social welfare which are of a rather different and potentially more troublesome kind, and this point will be returned to later.

The rather favourable interpretation of the Blair Government presented here is not a partisan one. Partisanship is best saved for the more important activity of football, but in so far as the writer has any political views they are not 'new Labour'. What is being presented here is an analytical perspective which suggests that a successful national economic policy in an era of globalization should have the following features:

1. It should be based on an ideology which embraces the intellectual and political supremacy of market forces.

2. This ideology should be translated into actions which demonstrate a proper respect for market forces.

3. Citizens should nevertheless be offered some protection against the harsher consequences of the market.

The Blair Government meets all three conditions and has been able to wrap up its overall approach to policy in a rhetoric of 'modernisation' which it is very difficult to challenge without appearing to be a defender of all that is archaic in Britain. It 
has pressed on with constitutional reform which offers the great advantage of being simultaneously modern and inexpensive. It has also been able to weave other images such as 'cool Britannia' which are essentially devoid of any real content. (For a critique of the Blair vision of modernity see Cockett, 1997).

This is not to say that the government has no vulnerabilities. It has met some presentational problems and finds it difficult to adjust to the fact that a government is open to much more critical media scrutiny than an opposition. Sometimes the sophistication of its spin doctoring has been self defeating. It also has a strong streak of social authoritarianism which at the moment seems in tune with the electorate but carries with it some risks if it is pushed too far.

These matters have to be mentioned to paint the broader picture, but they are not the focus of this paper. What needs to be discussed here is the way in which the three conditions outlined above have been met by the Blair Government. Before doing this, it should be noted that the government inherited an economy which was recognized by impartial observers as doing well. By 1996 the UK was in the fifth year of an economic recovery based on low inflation and a moderate but steady growth rate. Fifteen years of microeconomic reform had made the UK economy more flexible and competitive and less prone to inflation. (OECD, 1996).

\section{New Labour adjusts to globalization}

Labour's policy adjustments were not necessarily driven by globalization per se. In large part they were a response to domestic imperatives which meant that electoral success was perceived to be dependant on the party's ability to differentiate itself from 'old Labour'.

'New Labour' certainly showed itself able to embrace the philosophy of the market. Blair's analysis starts from the belief that:

The determining context of economic policy is the new global market. That imposes huge limitations of a practical nature ... on macroeconomic policies. (Financial Times, 22 May 1995).

As Blair made clear in his defining statement on economic policy in the 1995 Mais Lecture, 'The room for manoeuvre of any government in 
Britain is already heavily circumscribed.' (Financial Times, 23 May 1995). Given that Blair apparently views globalization as both a normative and empirical imperative, what is there left for government to do in the the sphere of economic policy? The report from the Commission on Public Policy, closely associated with leading figures in the Labour Party, argues that:

In a market economy, companies are the engine of wealth creation, but government has a supportive and collaborative role to play. (Commission on Public Policy, 1997, p.2).

Prime Minister Blair elaborated his own views of what he saw as the three key tasks for 'centre-left' governments in his meeting with President Clinton in February 1998:

One was that, as a result of globalization, it was essential that domestic governments held to fiscal and monetary prudence. second, that there was a role for government, but that was not in extensive economic regulation but in empowerment with the equipment of the individual to make the markets operate better. Thirdly, that we have to construct a tax and benefit system which was soumd and which helped to make work pay. (Senior British Official, 1998, p.1).

'Empowering the individual to make markets work better': this is a very different language from that used by the comparative political economists. It is interesting how Blair uses the phrase 'really successful businessman' as an accolade of high praise and how he has been keen to associate himself with entrepreneurs, figures that are absent from the landscape painted by the comparative political economists which is littered with associations, networks and various bodies endowed with public authority by the state. It has been suggested that he is particularly close to American trained business persons and that Britain has never had a government so well disposed to big business. As Blair made clear in his speech to the 1997 Labour conference, his vision of a modernised Britain is based on government harnessing private finance and working closely with companies.

Words are cheap, but the rhetoric has been matched by appropriate policy actions. One policy that was signalled before the election, and one that was something of a suprise, make this clear, although one policy experience after the election found the government 
accused of flirting with the old-style corporatism it has avowed to avoid.

An important part of the repackaging of new Labour was to overturn the traditional image of Labour as a 'tax and spend' party. Recently revealed public documents show that in the 1960s, the Labour Government saw increasing the public share of national income as an explicit policy goal. In contrast, new Labour pledged that it would adhere to the spending commitments of its Conservative predecessors for its first two years in office. Adjusting for inflation at 1996-7 prices, public expenditure peaked in real terms in 1995-6 at 262 billion. The 1997-8 planning total is 258.8 billion and that for 1998-9 258.1 billion.

A key policy change introduced immediately after the election was the decision to give the Bank's new monetary policy committee control over the setting of interest rates. A key policy lever is thus transferred away from the government to a setting more amenable to global economic forces. The main argument for moving the responsibility for fixing interest rates is that they are too important a policy instrument to be left to politicians. Monetary policy needs to be insulated from political influence in a global economy. It is hoped that the monetary policy committee will establish credibility with the markets, thus conferring a global blessing on the Blair Government as one that respects, and is in tune with, market forces.

The difficulties of the privatized coal industry showed, however, that the Government is vulnerable to short run pressures from its client groups. This episode cannot be dwelt on at length here, and it is by no means complete. In brief, the biggest coal mining company in Britain indicated that the closure of one colliery cold be followed by the closure of the majority of its pits. The Union of Democratic Mineworkers tried to cash in its rain check with the government. The initial response of the government was robust and could have been made by the Conservatives: there were no IOUs to the unions; it was not the job of government to intervene in the market; the matter was one for the commercial company involved which should price its product more realistically.

The deputy prime minister, John Prescott, called for a more interventionist approach and in December the Prime Minister prmised that there would be a deal between the coal company and the three 
big electricity generators which would stop pit closures for six months. Quite what the deal was was unclear, but it appeared that the generators would buy excess capacity and in return would get generous treatment under competition legislation or an easing of the vigilance of regulation. If this was the deal, then it sat ill with the government's devotion to the market and led to press criticism of 'corporatist fudge and government hand outs'. (Financial Times, 13 December 1997). In fact, one solution that did subsequently emrege from talks between one of the generators and the coal company was far more market oriented. Householders, particularly those in current and past coal mining areas, will be able to sign an electricity supply contract for coal fired electricity. The number of contracts signed would then be reflected in the amount of coal bought by the generator. The most recent indications (May 1998) are that the government is contemplating of taking the more interventionist step of imposed a moratorium on the construction of gas fired power stations in the name of an 'energy security' policy.

The third condition of a successful domestic policy response to globalization is offering citizens some protection against the harsher aspects of the international market. The government has advanced the notion of a 'third way' between the social democracy of the 'old left' and the neoliberalism of the 'new right'. The most authoritative statement to date of what this means has been provided by Anthony Giddens, the Director of the LSE who acts as a kind of informal court intellectual for the Blair Government. (Giddens, 1998). It is not possible to summarize his arguments in the space available here, but three need noting. First, what he terms 'the new mixed economy' refers 'to a balance between regulation and deregulation; and between the economic and non-economic in the life of the society.' (Giddens, 1998, p.19). Second, globalization leads to a softening of borders which revert to being frontiers. This means 'a nation sure enough of itself to accept the new limits to sovereignty' (Giddens, 1998, p.20). Third, 'Some of the criticisms offered by the new right about the welfare state are valid.' (Giddens, 1998, p.20). It needs to be reformed not to cut it back but to make it more responsive to changed circumstances.

The Blair Government does face a dilemma in the area of social protection. It does have a general strategy which is to try and forge in Europe a third way between what is seen as the historic over-regulation of labour markets in Europe and the unfettered market and insecurity seen to exist in the US. Making headway with 
this idea at the European level is difficult enough, but domestically the government faces the dilemma of, on the one hand, having promised to severely restrain public expenditure to retain the faith of the markets and, on the other hand, having promised the electors better health care and schools in order to win the election.

The government's way out of this dilemma is to 'rebuild' the welfare state which is the dominant element in public expenditure. The government rhetoric is that the welfare state has failed and needs to be reconstructed. The first steps along this route, reducing benefits to lone parents, led to considerable controversy. This is not surprising if one considers that ten years ago the notion that one of the first actions of a Labour Government would be to cut the benefits of a disadvantaged group in society would have seemed absurd. Even more trouble can be expected if and when global imperatives confront the disabled. There are good grounds for asking whether the rapidly spiralling budget for disabled benefits is well spent, but demonstrations by individuals in wheelchairs provide compelling visual images. The real storm will occur if and when the government tackles universal benefits like child benefits and the state pension, options which are evidently on the agenda. Limited public funds need to be redirected to activities more closely related to global competitiveness such as education, but those on already inadequate state pensions are not likely to see it that way.

The theory of a market economy, or more specific innovations such as changes in the way in which interest rates are set, are relatively remote from the lives of most people and government can appease global forces in those areas without having to pay a political price. The scenario becomes rather different when the focus shifts to benefits received by at least one member of most families. It is then that the crunch occurs between the economic forces of globalization and the preferences of individual citizens with the national government seeking to act as an intermediary. The result may be continuing diversities in provision from one country to another but this is not the kind of diversity that fascinates the comparative political economists.

\section{Conclusions: moving the agenda forward}

The real disagreement the writer has with some of the comparative political economists is that they acknowledge globalization, but 
fail to recognise the extent to which regionalisation might be a countervailing power (not to mention diversities protected at the subnational level). Streeck fears that what is happening at the European level is the reproduction of some parts of the German model (such as institutionalised monetarism) without those parts of the model which offer necessary social and institutional correctives. (Streeck, 1997, p.52). It is a powerful argument, but there may be more grounds for confidence about the institution building potential of the EU than streeck allows, particularly if it can become less preoccupied with the defence of marginal European farmers.

Even more effective regional institutions are, by themselves, not enough. There is a democratic deficit at the global level. Quite how it might be filled is difficult to predict, particularly given that the political orientation of citizens remains predominantly at the national and subnational levels. Strange sees transnational social movements as offering some potential and there are certainly a number which now operate globally. However, they remain relatively immature organisations. International firms may assume governance roles, but although they are organizationally mature, this is offset by a lack of legitimacy. In the short run, institutionalized negotiation and more effective enforcement regimes offered by bodies such as the World Trade Organization may offer the best way forward. At a European level, there is a need to develop the institutional capacities of the European Union in a way which citizens can relate to.

There is an important agenda to be addressed. National diversities will not disappear, although, as strange suggests, sectoral diversities may be as important. Unfortunately, some analysts in the comparative political economy school have a predisposition to celebrate the virtues of particular national models, rather than considering how those models might best adjust to a new international setting. One can build on Hall's work to suggest that there is an interesting set of questions about how one can maintain the better features of non-economic coordination arrangements in an era when globalization, broadly conceived, is a major force. 


\section{References}

Bean, C. and Crafts, N. (1996) 'British Economic Growth since 1945: Relative Economic Decline and Renaissance' in N.Crafts and G.Tolino (eds.) Economic Growth in Europe since 1945 (London: Cambridge University Press).

Borrus, M. and Zysman, J. (1997) 'Globalization with Borders: The Rise of Wintelism as the Future of Global Competition', Industry and Innovation, 1997, 141-66.

Cockett, R. (1997) 'The Lure of the New', New Statesman, 10 October $1997,23-4$.

Commission on Public Policy (1997) Promoting Prosperity: a Business Agenda for Britain (London: Vintage).

Crafts, N. (1997) Britain's Relative Economic Decline 1870-1995 (London: Social Market Foundation).

Crouch, C. and Streeck, W. (1997) 'Introduction: the Future of Capitalist Diversity' in C. Crouch and W. Streeck (eds.) Political Economy of Modern Capitalism: Mapping Convergence and Diversity (London: Sage), 1-18.

Fallows, J. (1989) More Like Us (Boston: Houghton Mifflin).

Giddens, A. (1998) 'After The Left's Paralysis', New Statesman, 1 May 1998, 18-21.

Grant, W. (1989) Government and Industry (Aldershot: Edward Elgar).

Hall, P. (1997) 'The Political Economy of Adjustment in Germany' in F Naschold and D Soskice (eds) WZB Jahrbuch 1997 (Berlin: Sigma).

Hall, P. (1998) 'Organized Market Economies and Unemployment in Europe: Is it Finally Time to Accept Liberal Orthodoxy?', paper presented at the Eleventh International Conference of Europeanists, Baltimore.

Hall, P. and Soskice, D. (eds.) (forthcoming) Varieties of Capitalism: the Formation of Comparative Institutional Advantage.

Nuti, F. and Cainelli, G. (1996) 'Changing Directions in Italy's Manufacturing Districts: the Case of the Emilian Footwear Districts of Fusignano and San Mauro Pascali', Journal of Industry Studies, 3, $105-118$.

OECD (1996) OECD Economic Surveys 1996: United Kingdom (Paris: OECD) .

Ohmae, K. (1990) The Borderless World: Power and Strategy in the Interlinked Economy (London: Collins).

Pontusson, J. (1997) 'Between Neo-Liberalism and the German Model: Swedish Capitalism in Transition', in C Crouch and W Streeck (eds) Political Economy of Modern Capitalism (London: Sage) •

Porter, M. (1990) The Competitive Advantage of Nations (London: Macmillan).

Senior British Official (1998) 'Background Briefing by American and British Senior Administration Officials and Spokesmen', Office of the Press Secretary, The White House, 6 February 1998. 
Shonfield, A. (1964)? Modern Capitalism: the Changing Balance of Public and Private Power (Oxford: Oxford University Press).

Strange, S. (1997) 'The Future of Global Capitalism: or Will Divergence Persist Forever?' in C. Crouch and W. Streeck (eds.) Political Economy of Modern Capitalism: Mapping Convergence and Diversity (London: Sage), 182-91.

Streeck, W. (1997) 'German Capitalism: Does it Exist? Can it Survive?', in C. Crouch and W. Streeck (eds.) Political Economy of Modern Capitalism: Mapping Convergence and Diversity (London: Sage), $33-54$.

Tamisari, M. (1997) 'Meeting the Challenges of Restructuring: Evolution of the Chair Manufacturing Industry in the Italian Region of Fruili', Industry and Innovation, 4, 233-46.

Vandenbroucke, F. (1998) 'Equality Remains a Key Value', New Statesman, 24 April 1998, 30. 